\title{
Penerapan Metode Barchart, CPM, PERT dan Crashing Project dalam Penjadwalan Proyek Pembangunan Gedung G Universitas Muhammadiyah Jember
}

\author{
Amri Gunasti, Ach. Rofiqi dan Pujo Priyono \\ ${ }^{1}$ Jurusan Teknik Sipil, Fakultas Teknik, Universitas Muhammadiyah Jember, Jember \\ ${ }^{2}$ Jurusan Teknik Sipil, Fakultas Teknik, Universitas Muhammadiyah Jember, Jember \\ ${ }^{3}$ Jurusan Teknik Sipil, Fakultas Teknik, Universitas Muhammadiyah Jember, Jember \\ E-mail:amrigunasti@unmuhjember.ac.id,achrofiqi76@gmail.com.
}

\begin{abstract}
ABSTRAK: Penelitian ini bertujuan untuk mengetahui percepatan serta membandingkan masing-masing metode. Hasil penelitian menunjukkan bahwa dengan menggunakan metode Barchat perhitungan awal dan perhitungan akhir dengan lama pengerjaan selama 44 minggu, metode CPM juga selama 44 minggu, metode CPM tidak bisa mengetahui jumlah anggaran dan hanya bisa mengetahui litasan kritis dengan metode perhitungan maju dan mundur. Metode PERT dengan meneliti 24\% kegiatan, selesai dengan 42 minggu. Untuk 99,11\% pekerjaan selesai dengan durasi 52 minggu dan 99,93\% pekerjaan selesai dengan durasi 62 minggu. Setelah dilakukan Crashing Project, durasi yang awalnya selama 44 minggu dengan jumlah hari 1320 hari mengalami percepatan sampai 1140 hari atau 38 minggu dengan selisih waktu 6 bulan dan jumlah anggaran yang harus di tambah adalah Rp. 2.390.418.814 dan dana keseluruhan yang harus di keluarkan adalah Rp. 7.217.353.814,29.
\end{abstract}

Kata kunci : penjadwalan, barchat, cpm, pert, crashing project.

\section{PENDAHULUAN}

Keberhasilan ataupun kegagalan dari pelaksanaan proyek konstruksi sering kali disebabkan kurang terencananya kegiatan proyek tersebut serta pengendalian yang kurang efektif. Akibat yang ditimbulkan adalah kegiatan proyek tidak efisien. Selain itu juga lebih dapat mengakibatkan keterlambatan, menurunnya kualitas pekerjaan, dan membengkaknya biaya pelaksanaan. Keterlambatan penyelesaian proyek adalah kondisi yang sangat tidak dikehendaki, karena hal ini dapat merugikan kedua belah pihak baik dari segi waktu maupun biaya. Dalam kaitannya dengan waktu dan biaya produksi, perusahaan harus bisa seefisien mungkin dalam penggunaan waktu di setiap kegiatan atau aktivitas, sehingga biaya dapat disesuaikan dengan perencanaan.

Proyek pada umumnya memiliki batas waktu (deadline), artinya proyek harus diselesaikan sebelum atau tepat pada waktu yang telah ditentukan. Namun pada kenyataannya di lapangan, suatu proyek tidak selalu berjalan sesuai dengan jadwal yang telah dibuat. Ada banyak faktor yang mengakibatkan hal tersebut terjadi, salah contoh turunnya hujan. Proses perencanaan kegiatan-kegiatan proyek merupakan masalah yang sangat penting. Perencanaan kegiatan merupakan dasar agar proyek bisa berjalan dan dilaksanakan serta dapat selesai dengan waktu yang optimal. Pada pembangunan gedung universitas muhammadiyah jember, banyak kegiatan yang tidak berjalan secara maksimal dan hal ini harus di tinjau ulang apakah ada masalah dari pihak manajemen atau ada kendala lain. Penulis tertarik untuk meneliti tentang penjadwalan pada proyek tersebut dengan menerapkan metode barchart, CPM, PERT dan Crashing Project dalam Penjadwalan dan percepatan pelaksanaan proyek Pembangunan Gedung G Universitas Muhammadiyah Jember, yang kerjakan oleh universitas muhammadiyah dengan sistem swabina. Adapun rumusan masalah dalam penelitian ini sebagai berikut:
1. Bagaimana Penerapan metode barchart, CPM, PERT dan Crashing Project pada pembangunan gedung G Universitas Muhammadiyah jember?

2. Bagaimana hasil Crashing project pada proyek pembangunan gedung $\mathrm{G}$ universitas muhammadiyah jember?

3. Bagaimana kelebihan dan kekurangan dari masingmasing metode perencanaan dan penjadwalan proyek tersebut?

\section{METODOLOGI PENELITIAN \\ Obyek Penelitian}

Obyek studi dari penelitian ini adalah proyek pembangunan Gedung $G$ Universitas Muhammadiyah Jember. Proyek ini memiliki nilai kontrak Rp. 4.826.900.000., dan dikerjakan dengan sistem swabina. Adapun durasi dari proyek adalah 45 Minggu atau 1320 Hari Kalender

\section{Lokasi Penelitian}

Lokasi penelitian proyek konstruksi yang dijadikan sebagai sample proyek adalah pembangunan Gedung $G$ (Gudang) universitas muhammadiyah jember Kab. jember.

\section{Metode Analisis Data}

Setelah data terkumpul akan dilakukan analisis data dan elaborasi dari penjadwalan proyek yang ada, berupa metode Bar Chart yang diubah ke dalam bentuk metode CPM, PERT dan Crashing Project.

\section{HASIL DAN PEMBAHASAN}

Data awal yang di peroleh dari proyek pembangunan gedung $G$ universitas muhammadiyah jember ini adalah metode linked Barchat, yang merupakan hasil dari perencanaan menggunakan microsof excel. Berikutnya 
data ini diolah menggunakan Software microsof project. Dari data metode penjadwalan tersebut terlihat bahwa hubungan logika ketergantungan yang digunakan antara satu item kegiatan dengan item kegiatan yang lain banyak menggunakan hubungan SS (Start to Start) dari pada 3 hubungan logika ketergantungan yang lain; SF (Start to Finish), FS (Finish to Start), FF (Finish to Finish).

\section{CPM (Critical Path Method)}

Pengerjaan proyek dengan metode CPM memperlihatkan logika ketergantungan. logika ketergantungan tersebut kemudian dibuat jaringan kerja atau network planning. Pembuatan jaringan kerja ini dimaksudkan untuk mengetahui jalur kritis.

Setelah diketahui jalur kritisnya maka dapat ditentukan kegiatan apasaja yang dapat di crash dari keseluruhan kegiatan yang ada pada proyek pembangunan gedung $G$ Universitas Muhammadiyah Jember tersebut. Bentuk jaringan kerja dari gambar gambar tersebut menunjukkan bahwa jalur kritis berada pada kegiatan $A$ B1-C1-D1-D7-D8-D4-D9.

\section{Project Evaluation Review Technique (PERT)}

Penjadwalan proyek dengan metode PERT, dimulai dengan mengestimasi waktu penyelesaian setiap item kegiatan proyek kedalam 3 jenis estimasi waktu yaitu waktu optimis (a), waktu yang paling mungkin (m) dan waktu pesimis (b). Estimasi ini didapat dari hasil wawancara dengan responden yang memiliki pengalaman dalam pengerjaan proyek dengan Project Evaluation Review Technique terdapat pada Tabel 1.

Tabel 1. Project Evaluation Review Technique

\begin{tabular}{|c|c|c|c|c|c|}
\hline No & Item pekerjaan & $\begin{array}{c}\operatorname{simb} \\
\text { ol }\end{array}$ & $\mathbf{A}$ & M & B \\
\hline $\mathbf{A}$ & $\begin{array}{l}\text { Pekerjaan } \\
\text { Persiapan }\end{array}$ & $\mathbf{A}$ & 4 & 4 & 6 \\
\hline B & $\begin{array}{l}\text { Pekerjaan } \\
\text { Lantai } 1\end{array}$ & B & & & \\
\hline 1 & $\begin{array}{l}\text { Pekerjaan Tanah } \\
\text { Dan Urugan }\end{array}$ & B1 & $\begin{array}{l}1 \\
2\end{array}$ & 15 & 23 \\
\hline 2 & $\begin{array}{l}\text { Pekerjaan } \\
\text { Pondasi }\end{array}$ & B2 & 4 & 8 & 15 \\
\hline 3 & Pekerjaan Beton & B3 & $\begin{array}{l}1 \\
7\end{array}$ & 19 & 28 \\
\hline 4 & $\begin{array}{l}\text { Pekerjaan } \\
\text { Pasangan } \\
\text { Dinding } \\
\end{array}$ & B4 & 5 & 8 & 18 \\
\hline 5 & $\begin{array}{l}\text { Pekerjaan } \\
\text { finishing lantai } \\
\text { dan dinding }\end{array}$ & B5 & 8 & 12 & 20 \\
\hline 6 & $\begin{array}{l}\text { Pekerjaan Cat } \\
\text { Catan }\end{array}$ & B6 & 8 & 13 & 18 \\
\hline 7 & $\begin{array}{l}\text { Pekerjaan Pintu } \\
\text { Dan Cendela }\end{array}$ & B7 & $\begin{array}{l}1 \\
0\end{array}$ & 15 & 20 \\
\hline 8 & $\begin{array}{l}\text { Pekerjaan } \\
\text { Elektrical }\end{array}$ & B8 & 8 & 10 & 14 \\
\hline 9 & $\begin{array}{l}\text { Pekerjaan } \\
\text { Sanitasi }\end{array}$ & B9 & 6 & 12 & 15 \\
\hline $\mathbf{C}$ & $\begin{array}{l}\text { Pekerjaan } \\
\text { Lantai } 2\end{array}$ & $\mathbf{C}$ & & & \\
\hline 1 & Pekerjaan Beton & C1 & $\begin{array}{l}1 \\
3 \\
\end{array}$ & 18 & 25 \\
\hline
\end{tabular}

\begin{tabular}{|c|c|c|c|c|c|}
\hline 2 & $\begin{array}{l}\text { Pekerjan } \\
\text { Pasangan } \\
\text { Dinding }\end{array}$ & $\mathrm{C2}$ & 5 & 10 & 15 \\
\hline 3 & $\begin{array}{l}\text { Pekerjaan } \\
\text { Finishing Lantai } \\
\text { Dan Dinding }\end{array}$ & C3 & 4 & 6 & 10 \\
\hline 4 & $\begin{array}{l}\text { Pekerjaan Cat } \\
\text { Catan }\end{array}$ & C4 & 4 & 6 & 8 \\
\hline 5 & $\begin{array}{l}\text { Pekerjaan Pintu } \\
\text { Dan Cendela }\end{array}$ & C5 & 4 & 8 & 14 \\
\hline 6 & $\begin{array}{l}\text { Pekerjaan } \\
\text { Elektrical }\end{array}$ & C6 & 3 & 6 & 12 \\
\hline D & $\begin{array}{l}\text { Pekerjaan } \\
\text { Lantai } 3\end{array}$ & D & & & \\
\hline 1 & Pekerjaan Beton & D1 & 7 & 15 & 20 \\
\hline 2 & $\begin{array}{l}\text { Pekerjaan } \\
\text { Pasangan } \\
\text { Dinding } \\
\end{array}$ & D2 & 5 & 10 & 15 \\
\hline 3 & $\begin{array}{l}\text { Pekerjaan } \\
\text { Finishing Lantai } \\
\text { Dan Dinding }\end{array}$ & D3 & 4 & 8 & 12 \\
\hline 4 & $\begin{array}{l}\text { Pekerjaan Cat } \\
\text { Catan }\end{array}$ & D4 & 6 & 8 & 10 \\
\hline 5 & $\begin{array}{l}\text { Pekerjaan Pintu } \\
\text { Dan Cendela }\end{array}$ & D5 & 4 & 6 & 10 \\
\hline 6 & $\begin{array}{l}\text { Pekerjaan } \\
\text { Elektrical }\end{array}$ & D6 & 2 & 2 & 8 \\
\hline 7 & $\begin{array}{l}\text { Pekerjaan } \\
\text { Plafond } \\
\end{array}$ & D7 & 4 & 8 & 10 \\
\hline 8 & $\begin{array}{l}\text { Pekerjaan } \\
\text { Rangka Atap } \\
\text { Dan Penutup } \\
\text { Atap }\end{array}$ & D8 & $\begin{array}{l}1 \\
0\end{array}$ & 12 & 15 \\
\hline 9 & $\begin{array}{l}\text { Pekerjaan } \\
\text { Exterior } \\
\text { Pendukung }\end{array}$ & D9 & $\begin{array}{l}1 \\
5\end{array}$ & 15 & 20 \\
\hline
\end{tabular}

Setelah membuat estimasi waktu maka dicari niali te (waktu yang diharapkan) yang terdapat pada Tabel 2 dengan menggunakan rumus

$$
t y=\frac{n+4 m+b}{6} .
$$

Dimana:

$$
\begin{aligned}
& \text { te }=\text { waktu yang diharapkan } \\
& a=\text { waktu optimis } \\
& b=\text { waktu pesimis } \\
& m=\text { waktu paling mungkin }
\end{aligned}
$$

Tabel 2. Nilai waktu yang diharapkan (te)

\begin{tabular}{|l|l|l|l|}
\hline No & \multicolumn{1}{|c|}{ Item Pekerjaan } & $\begin{array}{c}\text { Simb } \\
\text { ol }\end{array}$ & $\begin{array}{c}\text { Te } \\
\text { (Minggu) }\end{array}$ \\
\hline A & $\begin{array}{l}\text { Pekerjaan } \\
\text { Persiapan }\end{array}$ & A & 4,3 \\
\hline B & $\begin{array}{l}\text { PEKERJAAN } \\
\text { LANTAI 1 }\end{array}$ & B & \\
\hline 1 & $\begin{array}{l}\text { Pekerjaan Tanah Dan } \\
\text { Urugan }\end{array}$ & B1 & 13 \\
\hline 2 & Pekerjaan Pondasi & B2 & 8,5 \\
\hline 3 & Pekerjaan Beton & B3 & 20,1 \\
\hline 4 & $\begin{array}{l}\text { Pekerjaan Pasangan } \\
\text { Dinding }\end{array}$ & B4 & 9,1 \\
\hline 5 & Pekerjaan finishing & B5 & 12,6 \\
\hline
\end{tabular}


Jurnal Rekayasa Tenik Sipil Universitas Madura Vol. 4 No.1 Juni 2019 ISSN 2527-5542

\begin{tabular}{|l|l|l|l|}
\hline & lantai dan dinding & & \\
\hline 6 & Pekerjaan Cat Catan & B6 & 13 \\
\hline 7 & $\begin{array}{l}\text { Pekerjaan Pintu Dan } \\
\text { Cendela }\end{array}$ & B7 & 15 \\
\hline 8 & Pekerjaan Elektrical & B8 & 10,3 \\
\hline 9 & Pekerjaan Sanitasi & B9 & 11,5 \\
\hline C & $\begin{array}{l}\text { PEKERJAAN } \\
\text { LANTAI 2 }\end{array}$ & C & \\
\hline 1 & Pekerjaan Beton & C1 & 18,3 \\
\hline 2 & $\begin{array}{l}\text { Pekerjan Pasangan } \\
\text { Dinding }\end{array}$ & C2 & 10 \\
\hline 3 & $\begin{array}{l}\text { Pekerjaan Finishing } \\
\text { Lantai dan Dinding }\end{array}$ & C3 & 8 \\
\hline 4 & Pekerjaan Cat Catan & C4 & 7,7 \\
\hline 5 & $\begin{array}{l}\text { Pekerjaan Pintu Dan } \\
\text { Cendela }\end{array}$ & C5 & 8,3 \\
\hline 6 & Pekerjaan Elektrical & C6 & 6,5 \\
\hline D & $\begin{array}{l}\text { PEKERJAAN } \\
\text { LANTAI 3 }\end{array}$ & D & \\
\hline 1 & Pekerjaan Beton & D1 & 14,5 \\
\hline 2 & $\begin{array}{l}\text { Pekerjaan Pasangan } \\
\text { Dinding }\end{array}$ & D2 & 10 \\
\hline 3 & $\begin{array}{l}\text { Pekerjaan Finishing } \\
\text { Lantai Dan Dinding }\end{array}$ & D3 & 8 \\
\hline 4 & Pekerjaan Cat Catan & D4 & 8 \\
\hline 5 & $\begin{array}{l}\text { Pekerjaan Pintu Dan } \\
\text { Cendela }\end{array}$ & D5 & 6,3 \\
\hline 6 & Pekerjaan Elektrical & D6 & 3 \\
\hline 7 & Pekerjaan Plafond & D7 & 7,6 \\
\hline 8 & $\begin{array}{l}\text { Pekerjaan Rangka } \\
\text { Atap Dan Penutup }\end{array}$ & D8 & 12,2 \\
\hline 9 & $\begin{array}{l}\text { Pekerjaan Exterior } \\
\text { Pendukung }\end{array}$ & D9 & 15,9 \\
\hline & & & \\
\hline
\end{tabular}

\begin{tabular}{|l|c|c|c|c|c|}
\hline Plafond & & & & & 9 \\
\hline $\begin{array}{l}\text { Pekerjaan } \\
\text { Rangka Atap } \\
\text { Dan Penutup } \\
\text { Atap }\end{array}$ & D8 & 10 & 12 & 0,4 & 0,1 \\
\hline $\begin{array}{l}\text { Pekerjaan Cat- } \\
\text { Catan }\end{array}$ & D4 & 6 & 8 & 0,3 & 0,0 \\
\hline$\sum V(T e)$ & \multicolumn{5}{|c|}{9,33} \\
\hline $\begin{array}{c}\text { Standart } \\
\text { Devisiasi }\end{array}$ & \multicolumn{5}{|c}{} \\
\hline
\end{tabular}

Dari Tabel 3 diatas dapat di ketahui nilai total varians $\left(\sum \mathrm{V}(\mathrm{Te})\right)=9,33$ dan $(\mathrm{S})=14,3$. Dari sifat kurva distribusi normal dimana $99,7 \%$ area berada dalam interval $(\mathrm{TE}-3 \mathrm{~S})$ dan $(\mathrm{TE}+3 \mathrm{~S})$ maka besar rentang $3 \mathrm{~S}$ Adalah 3 x 1,13=3,39. Maka kurun waktu penyelesaian proyek paling cepat adalah 7,5- 3,39=4,11 minggu dan perkiraan penyelesaian proyek paling lambat 7,5 $+3,39=$ 10,89 minggu jika dalam hal ini yang ingin di capai adalah kurun waktu yang paling cepat, maka nilai T(d) 42 Minggu

Kemungkinan/ketidakpastian mencapai target jadwal pada PERT dinyatakan dengan $\mathrm{Z}$

$$
\begin{aligned}
& \text { Deviasi } Z=\frac{T(d)-T E}{S} \\
& \text { Dimana } Z=\frac{42-75}{14,3}
\end{aligned}
$$

$$
=2,41
$$

Dengan menggunakan tabel distribusi normal kumulatif dengan harga $\mathrm{z}=2,77$ maka di peroleh hasil 0,0024 . Ini kemungkinan proyek untuk selesai dalam jangka waktu 42 minggu hanya sekitar $0,24 \%$.

Dari hasil analisis dapat diketahui bahwa:

1. Kemungkinan proyek dapat di selesaikan dalam waktu 42 minggu adalah $0,24 \%$.

Dengan menggunakan nilai te (durasi waktu yang diharapkan) maka dibuatlah sebuah diagram jaringan kerja proyek. Dimana prinsip pembuatan jaringan kerja ini sama seperti pada metode CPM.

Hasil analisa penjadwalan dengan metode PERT dengan nilai te sebagai durasi yang digunakan dalam perhitungan, maka diketahui jalur kritis diagram jaringan kerja pada kegiatan $A-B 1-C 1-D 1-D 7-D 8-D 4-D 9$

Berdasarkan lintasan kritis yang telah kemudian tentukan nilai deviasi standard (Tabel 3) dapat di cari dengan rumus

Vte $=S^{2}$

Tabel 3. Deviasi Standard

\begin{tabular}{|l|c|c|c|c|c|}
\hline \multicolumn{1}{|c|}{$\begin{array}{c}\text { Item } \\
\text { Pekerjaan }\end{array}$} & $\begin{array}{c}\text { sim } \\
\text { bol }\end{array}$ & a & b & s & $\begin{array}{c}\text { V(te } \\
\text { ) }\end{array}$ \\
\hline $\begin{array}{l}\text { Pekerjaan } \\
\text { Pendahuluan }\end{array}$ & A & 4 & 6 & 0,3 & $\begin{array}{c}0,0 \\
9\end{array}$ \\
\hline $\begin{array}{l}\text { Pekerjaan } \\
\text { Tanah Dan } \\
\text { Urugan }\end{array}$ & B1 & 12 & 15 & 0,5 & $\begin{array}{c}0,2 \\
5\end{array}$ \\
\hline $\begin{array}{l}\text { Pekerjaan } \\
\text { Beton }\end{array}$ & $\mathrm{C} 1$ & 13 & 18 & 0,9 & 0,8 \\
\hline $\begin{array}{l}\text { Pekerjaan } \\
\text { Beton }\end{array}$ & D1 & 7 & 15 & 1,2 & $\begin{array}{c}1,4 \\
4\end{array}$ \\
\hline Pekerjaan & D7 & 4 & 8 & 0,7 & 0,4 \\
\hline
\end{tabular}
waktu 52, 54 minggu atau 52 minggu adalah 99,11\%

3. Kemungkina proyek dapaat dilesaikan dalam waktu 62 minggu adalah $99,93 \%$.

\section{Crashing Project}

Produktivitas harian percepatan diperoleh dari jumlah produktivitas harian normal dengan produktivitas pekerjaan saat jam lembur per hari. Penambahan jam kerja lembur sesuai Peraturan yang berlaku dilakukan selama 3 jam per hari, sedangkan produktivitas pekerja jam lembur diasumsikan mengalami penurunan, dan hanya diperhitungkan sebesar $80 \%$ dari produktivitas jam kerja regular.

Langkah-langkah perhitungan produktivitas harian percepatan pekerjaan kritis adalah sebagai berikut :

a. Menghitung volume pekerjaan

b. Menghitung durasi normal

c. Menghitung produktivitas harian normal

d. Produktivitas normal/jam

e. Produktivitas jam lembur

f. Produktivitas harian percepatan

Untuk memperjelas maka akan dihitung salah satu item sebagai contoh. Perhitungan produktivitas harian normal pada Pengeboran Tanah Bor Pile sedalam $4 \mathrm{~m}$ :

a. Volume pekerjaan $=432$

b. Harga satuan $=$ Rp. $5000,000,00$ 
c. $\quad$ Durasi normal $=4$ minggu (30 Hari)

d. Produktivitas harian normal $=\mathrm{a} / \mathrm{d}$

$=432 / 30$

$=36 \mathrm{~m}^{3}$

e. Produktifitas normal perjam

$=\mathrm{d} / 8$

$=36 / 8 \mathrm{jam}$

$=4,5$

f. Produktifitas jam lembur $=3 \times$ ex 0,80

$=3 \times 4,5 \times 0,80$

$=10,8 \mathrm{~m}^{3 / \mathrm{jam}}$

g. Produktifitas harian percepatan $=(\mathrm{e} \times \mathrm{f}) \times 8$

$=(4,5 \times 10,8) \times 8$

$=122,4 \mathrm{~m}^{3 \text { hari }}$

\section{Perhitungan Crash Duration, Crash Cost, dan Cost Slope}

Setelah diketahui besarnya produktivitas harian percepatan pekerjaan kritis, maka langkah selanjutnya adalah menghitung durasi percepatan (crash duration) dan biaya langsung percepatan (crash cost). Perhitungan crash duration ini digunakan untuk mendapatkan batasan waktu maksimal suatu aktivitas mampu untuk dilakukan crashing (crashability), sedangkan perhitungan crash cost digunakan untuk mencari slope biaya (cost slope) masingmasing aktivitas.

Untuk menentukan Crash Cost dapat dilakukan dengan langkah-langkah berikut:

a. Menghitung upah kerja harian normal, yaitu produktivitas harian $\mathrm{x}$ harga satuan upah kerja.

b. Menghitung upah kerja normal, yaitu produktivitas per jam $\mathrm{x}$ harga satuan upah kerja

c. Menghitung upah kerja lembur per hari:

1. Untuk 3 jam lembur $=(1,5 \mathrm{x}$ upah sejam normal $)+$ $2(2 \times$ upah sejam normal).

2. Untuk 4 jam lembur $=(1,5 \mathrm{x}$ upah sejam normal $)+$ 3 (2 $\mathrm{x}$ upah sejam normal).

3. Menghitung Crash Cost per hari, yaitu upah harian + upah kerja lembur per hari.

Untuk memperjelas maka akan dihitung salah satu item sebagai contoh. Perhitungan crash duration, crash cost, dan cost slope untuk pekerjaan Boer Pile D 0.3m, T $4 \mathrm{~m}$ sebagai berikut:

a. Volume pekerjaan $=30,5208 \mathrm{~m} 3$

b. Durasi percepatan $=29$ hari

c. Normal cost $=$ Rp. 111.951 .549

d. Durasi normal $=30$ hari $(4 \mathrm{minggu})$

e. Produktifitas normal /hari $\mathrm{m} 3 /$ jam

$=\mathrm{a} / \mathrm{d}$

$=30,5208 \mathrm{~m} 3 / 30$ hari

$=2,347753846$

f. Produktifitas normal per/jam m3

$=\mathrm{e} / 8$

$=2,347753846 / 8$

$=0,293469231$

g. Produktifitas lembur/hari

$=3 \times \mathrm{f} \times 0,8$

$=3 \times 0,293469231 \times 0,8$

$=0,704326154$

h. Produktifias harian percepatan

$=(\mathrm{f}+\mathrm{g}) \times 8$

$=(0,293469231+0,704326154) \times 8$
$=7,982363077$

i. Crash Duration

$=\mathrm{b}-(\mathrm{a} / \mathrm{h} / 8)$

$=29-(30,5208 \mathrm{~m} 3 / 7,982363077 \times 8)$

$=28,52205882$

j. Upah normal/jam

$=\mathrm{d} \times \mathrm{g}$

$=30$ hari $(4$ minggu $) \times 0,704326154$

$=\operatorname{Rp} 2.583 .497$

$\mathrm{k}$. Upah normal per/ hari

$=\mathrm{j} \times 8$

$=\mathrm{Rp} 2.583 .497 \mathrm{x} 8$

$=\operatorname{Rp} 20.667 .978$

1. Upah 3 jam lembur/ hari

$=(1,5 \times \mathrm{J})+2 \times(2 \times \mathrm{j})$

$=(1,5 \times$ Rp. $2 \cdot 583.497)+2(2 \times$ Rp.

2.583.497)

$=\mathrm{Rp} 14.209 .235,04{ }^{\prime}$

m. Cost Upah Percepatan perhari

$=(\mathrm{c}+1)$

$=$ Rp.111.951.549 + Rp14.209.235,04.'

=Rp. 4.423.271,00

n. Cost upah perhari

$=\mathrm{c}+\mathrm{m}$

$=$ Rp. 111.951.549,00+Rp. 4.423.271,00

$=$ Rp. 116.374.819,42

o. Cost bahan

$=\mathrm{a} \times \mathrm{e}$

$=30,5208 \mathrm{~m} 3 \times 2,347753846$

$=\mathrm{Rp} \operatorname{Rp} 71,66000,00$

p. Cost alat

$=\mathrm{a} \times \mathrm{f}$

$=30,5208 \mathrm{~m} 3 \times 0,293469231$

$=$ Rp. 8,960,000,00

q. Crash Cost

$=\mathrm{n}+\mathrm{o}+\mathrm{p}$

$=$ Rp. 116.374.819,42+Rp. 8,960,000,00

+ Rp. 8,960,000,00

$=\mathrm{Rp} 116.374 .900,03$

r. Crash slope

$=\mathrm{q}-\mathrm{c} / \mathrm{b}-\mathrm{i}$

$=$ Rp116.374.900,03 - Rp. 111.951.549/30

hari - 29 hari

$=$ Rp. 4.423.351,20 per hari

\section{Analisis Waktu dan Biaya Optimum}

Setelah dilakukan Perhitungan Crash duration, Crash Cost, dan Cost Slope, kemudiandilakukan analisis waktu dan biaya optimum setelah percepatan sebagai berikut :

1. Rencana Anggaran biaya proyek dengan waktu 1320 hari hari sebesar : = Rp. 4.826.900.000

2. Biaya percepatan dengan penambahan tenaga kerja sebagai berikut :

Biaya percepatan pada pekerjaan Kritis - Biaya Normal pada pekerjaan kritis $=$ Rp. 2.390.418.814.000

3. Keuntungan pihak pengelola sebesar $15 \%$ $=$ Rp. $4.826 .900 .000 \times 15 \%$

$=\mathrm{Rp} 724.035 .000$

4. Total biaya setelah dikurangi keuntungan pihak pengelola sebesar $15 \%$ 
$=$ Rp. 4.826.900.000 - Rp724.035.000

$=$ Rp. 4.102.865.000

5. Keuntungan Kontraktor setelah percepatan :

$=$ Rp724.035.000 - Rp. 2.390.418.814

$=$ Rp. 3.114.453.814,29

6. Biaya proyek dengan penambahan tenaga kerja adalah :

Rencana anggaran proyek + biaya penambahan tenaga kerja

$=$ Rp. 4.826.900.000 + Rp. 2.390.418.814

$=$ Rp. 7.217.353.814,29

Dengan demikian hubungan antara biaya dan waktu untuk menyelesaikan percepatan pekerjaan Pembangunan Jembatan Sei Hanyu Kabupaten Kapuas seperti pada Gambar 4 berikut :

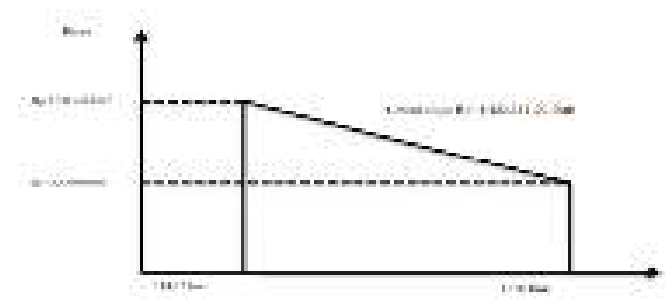

Gambar 4. Hubungan Antara Waktu dan Biaya

\section{Analisa komparasi}

Ada perbedaan antara masing-masing metode yang dihasilkan dalam penelitian ini seperti yang terdapat pada Tabel 4 berikut.

Tabel 4. Perbandingan Masing-Masing Metode

\begin{tabular}{|c|c|c|}
\hline $\begin{array}{c}\text { Perba } \\
\text { nding } \\
\text { an }\end{array}$ & $\begin{array}{l}\text { Penggunaan } \\
\text { metode }\end{array}$ & $\begin{array}{c}\text { Perhitungan percepatan } \\
\text { Produksi }\end{array}$ \\
\hline $\begin{array}{l}\text { BarCh } \\
\text { at }\end{array}$ & $\begin{array}{l}\text { Dapat digunakan } \\
\text { untuk penjadwalan } \\
\text { proyek apasaja. }\end{array}$ & $\begin{array}{l}\text { Dengan cara perhitungan } \\
\text { jumlah komulatif bobot } \\
\text { pekerjaan }\end{array}$ \\
\hline CPM & $\begin{array}{lr}\text { Mudah } & \text { untuk } \\
\text { update dan } & \text { cocok } \\
\text { untuk } & \text { yang } \\
\text { kmplek } & \end{array}$ & Tidak di ketahui \\
\hline Pert & $\begin{array}{lr}\text { Cocok } & \text { untuk } \\
\text { evaluasi } & \text { proyek } \\
\text { dan analisi rasiko }\end{array}$ & Tidak diketahu \\
\hline $\begin{array}{l}\text { Creas } \\
\text { hing } \\
\text { projek }\end{array}$ & $\begin{array}{l}\text { Cocok buat proyek } \\
\text { apasaja dan bisa } \\
\text { di gunakan sebagai } \\
\text { evaluai keuangan }\end{array}$ & $\begin{array}{l}\text { Dengan cara menghitung } \\
\text { volume, harga normal dan } \\
\text { hasil dari percepatan. }\end{array}$ \\
\hline $\begin{array}{c}\text { Perba } \\
\text { nding } \\
\text { an }\end{array}$ & $\begin{array}{c}\text { Logika } \\
\text { ketergantungan }\end{array}$ & Lintasan kritis \\
\hline $\begin{array}{l}\text { BarCh } \\
\text { at }\end{array}$ & $\begin{array}{l}\text { Tidak dapat } \\
\text { menunjukkan } \\
\text { secara spesifik } \\
\text { hubungan logika } \\
\text { ketergantungan } \\
\text { antar kegiatan }\end{array}$ & Tidak diketahu \\
\hline CPM & $\begin{array}{l}\text { Menggunakan } \\
\text { hubungan logika } \\
\text { ketergantungan FS } \\
\text { (Finist To Start) }\end{array}$ & $\begin{array}{l}\text { Dapat di ketahui yaitu } \\
\text { litasan kritis pada proyek } \\
\text { pembangunan gedung G } \\
\text { universitas }\end{array}$ \\
\hline
\end{tabular}

\begin{tabular}{|c|c|c|}
\hline & saja & $\begin{array}{l}\text { muhammadiyah jember } \\
\text { adalah } A-B 1-C 1-D 1-D 7- \\
D 8-D 4-D 9 \text {. }\end{array}$ \\
\hline PERT & $\begin{array}{lr}\text { Mengikuti } & \mathrm{cpm} \\
\text { yaitu } & \text { logoka } \\
\text { ketergantungan }\end{array}$ & $\begin{array}{l}\text { Dapat di ketahui yaitu } \\
\text { litasan kritis pada proyek } \\
\text { pembangunan gedung } \mathrm{G} \\
\text { universitas } \\
\text { muhammadiyah jember } \\
\text { adalah } A-B 1-C 1-D 1-D 7- \\
D 8-D 4-D 9 \text {. }\end{array}$ \\
\hline $\begin{array}{l}\text { Crash } \\
\text { ing } \\
\text { Projec } \\
t\end{array}$ & $\begin{array}{lr}\text { Mengikuti } & \mathrm{cpm} \\
\text { yaitu } & \text { logoka } \\
\text { ketergantungan }\end{array}$ & $\begin{array}{l}\text { Dapat di ketahui yaitu } \\
\text { litasan kritis pada proyek } \\
\text { pembangunan gedung } \mathrm{G} \\
\text { universitas } \\
\text { muhammadiyah jember } \\
\text { adalah } A-B 1-C 1-D 1-D 7- \\
D 8-D 4-D 9 \text {. }\end{array}$ \\
\hline $\begin{array}{c}\text { Perba } \\
\text { nding } \\
\text { an }\end{array}$ & $\begin{array}{l}\text { Hambatan pada } \\
\text { aktifitas kegiatan }\end{array}$ & Main feature \\
\hline $\begin{array}{l}\text { Barch } \\
\text { at }\end{array}$ & Tidak diketahui & $\begin{array}{l}\text { Bagan balok tersendiri } \\
\text { atas sumbu Y yang } \\
\text { menyatakan kegiatan dan } \\
\text { sumbu x menyatkan durasi } \\
\text { waktu }\end{array}$ \\
\hline CPM & Tidak di ketahui & $\begin{array}{l}\text { Kegiatan terletak pada } \\
\text { anak panah dan diantara } 2 \\
\text { titik (node). }\end{array}$ \\
\hline PERT & Tidak diketahui & $\begin{array}{l}\text { Teknik diangram jaringan } \\
\text { yang mempertimbangkan } \\
\text { penggunaan durasi tak } \\
\text { tentu sehingga } \\
\text { memberikan kemungkinan } \\
\text { penyelesaian proyek } \\
\text { dengan } 3 \text { macam durasi } \\
\text { Tampilan menggunakan } \\
\text { pendekatan CPM. }\end{array}$ \\
\hline $\begin{array}{l}\text { Crash } \\
\text { ing } \\
\text { Projec } \\
t\end{array}$ & - & - \\
\hline
\end{tabular}

\section{KESIMPULAN}

Dari hasil penelitian secara keseluruhan didapat bahwa:

1. Metode pada jaringan kerja CPM diketahui bahwa lintasan kritis pada pembangunan gedung $G$ universitas muhammadiyah jember adalah $A-B 1-C 1$ D1-D7-D8-D4-D9.

2. Metode PERT menggunakan 3 macam durasi waktu untuk masing masing kegiatan, yaitu waktu optimis (a), waktu yang paling mungkin (m) dan waktu pesimis (b). Kemungkinan proyek dapat di selesaikan dalam waktu 42 minggu adalah 0,24\%. Kemungkinan proyek dapat di selesaikan dalam waktu 52, 54 minggu atau 52 minggu adalah 99,11\%. Kemungkina proyek dapaat dilesaikan dalam waktu 62 minggu adalah $99,93 \%$.

3. Dengan adanya percepatan penyelesaian diperlukan tambahan biaya Rp. 2.390.418.814 (Cost Slope). 
Jurnal Rekayasa Tenik Sipil Universitas Madura Vol. 4 No.1 Juni 2019 ISSN 2527-5542

Sebesar Rp. 4.423.351,20/hari sehingga penambahan biaya sebesar Rp. 7.217.353.814,29 dari perencanaan Rp. 4.826.900.000

\section{SARAN}

1. Perlu adanya pengembangan lebih lanjut prihal penerapan metode dalam proyek manajemen kontruksi dan penjadwalan proyek.

2. Karena metode barchat belum dapat memberikan penjelasan yang runtut maka harus ada penngembangan metode lebih dalam supaya dalam penjadwalan proyek lebih jelas.

3. Hasil durasi dan biaya optimum yang di peroleh dari metode crashing dapat di pertimbangkan penerapanya dalam melaksakan pekerjaan proyek kontruksi . hal ini menunjukkan durasi pelaksaan yang lebih singkat dan akan membutuhkan biaya yang lebih besar dibandingkan dari perencanaan awal. Akan tetapi tidak akan membuat cost pengelola rugi dalam melaksanakan proyek.

\section{DAFTAR PUSTAKA}

Adoe, M., (2010). Identifikasi Faktor Penyebab Keterlambatan Pelaksanaan Proyek Kontruksi Gedung. Jurusan Teknik Sipil, Fakultas Teknik Sipil Universitas Nusa Cendana, Kupang.

Bush, V. G. (1994). Manajemen kontruksi. Jakarta: PT Pustaka Binaan Presindo.

Dannyati, E, (2010). Optimalisasi pelaksanaan proyek dengan metode PERT dan CPM. Fakultas ekonomi. Universitas diponogoro. Semarang

Gunasti, A. (2015). Faktor-Faktor yang Mempengaruhi Kinerja Manajer Proyek pada Proyek Konstruksi. Jurnal Media Teknik Sipil, 13(1), 31-36.

Gunasti, A. (2017). Penilaian Kinerja Peladen Dan Harapan Tukang Dalam Proyek Konstruksi. Teknik Sipil, Universitas Muhammadiyah Jember.

Gunasti, A. (2017). Penilaian Kinerja Tukang Dan Harapan Mandor Dalam Proyek Konstruksi. Jurnal Penelitian IPTEKS, 2(1).

Gunasti, A. (2017). "Penilaian Standar Kompetensi Kerja Tukang Besi/Beton Pada Proyek Konstruksi Di Kabupaten Jember. Rekayasa: Jurnal Sipil 2.2 (2017): 13-18.

Gunasti, A. (2018). "Penilaian Standar Kompetensi Kerja Tukang Besi/Beton Pada Proyek Konstruksi Di Kabupaten Jember. Rekayasa: Jurnal Sipil 3(1),714, 2018

Hayun, Anggara, (2005). "perencanaan dan pengendalian proyek dengan metode pert-cpm : studi kasus fly Over Ahmad Yani, Karawang," Journal the winners, Vol. 6, No.2, h-155-174

Irika Widiansanti, M. L. (2013). Manajemen Kontruksi. jakarta: ROSDA.

Oetomo, W., Prioto, \& Uhad. (2017). Analisis Waktu Dan Biaya Dengan Metode Crash Duration Pada Keterlambatan Proyek Pembangunan Jembatan Sei Hanyu Kabupaten Kapuas. Media Ilmiah Teknik Sipil, 08-22.

Ridho, M. R., \& Syahrizal. (2012). Evaluasi Penjadwalan Waktu Dan Biaya Proyek Dengan Metode Pert Dan Cpm (Studi kasus : Proyek Pembangunan Gedung
Kantor Badan Pusat Satatistik Kota Medan di Jl. Gaperta Medan, Sumatra Utara). departemen teknik sipil, universitas sumatra utara, 30-33.

Soeharto, Iman (1995). Manajemen Proyek: Dari Konseptual Sampai Operasional: Erlangga. 